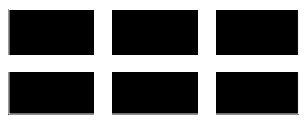

ThE WiLliam DAVIDSON INSTITUTE AT THE UNIVERSITY OF MICHIGAN BUSINESS SCHOOL

\title{
Participation Behavior of East German Women after German Unification
}

\author{
By: Holger Bonin and Rob Euwals
}

William Davidson Working Paper Number 477

July 2002 


\title{
Participation Behavior of East German Women
}

\author{
after German Unification*
}

\author{
Holger Bonin \\ IZA, Bonn \\ Rob Euwals \\ IZA, Bonn, and CEPR, London
}

July 2002

\begin{abstract}
The paper studies the determinants of labor force participation by East German women after unification. To isolate the role of preferences on labor force participation from individual characteristics, we develop a panel data model that simultaneously explains participation, employment, and wages. The model, estimated for East and West Germany on the basis of the German Socio-Economic Panel, indicates that distinct preferences could explain the regional difference in participation rates at unification. Afterward East German women became less willing to participate, but the negative participation trend was offset on the aggregate level by changes in characteristics and wages promoting participation.
\end{abstract}

KEYWORDS: Transitional Economies, Labor Force Participation, Panel Data.

JEL CLASSIFICATION: C33, J21, J31

CONTACT: bonin@iza.org; euwals@iza.org

\footnotetext{
* We wish to thank Hilmar Schneider, Arthur van Soest, Rainer Winkelmann, participants of the $16^{\text {th }}$ ESPE Conference in Bilbao, the $2^{\text {nd }}$ IZAWDI International Conference in San José, the $5^{\text {th }}$ International GSOEP User Conference in Berlin, the $10^{\text {th }}$ International Conference on Panel Data in Berlin, and of the seminars at IZA and IW Halle for their helpful comments. The authors gratefully acknowledge DIW for providing the data.
} 


\section{Introduction}

A peculiarity of the former German Democratic Republic, like of several of her former EasternEuropean partner states, was the high involvement of women in the labor force. Before the collapse of the communist system, more than $80 \%$ of women at working age participated in the labor market - a rate only comparable to the achievement of Scandinavian countries like Denmark and Sweden. In particular, it appears that women in the German Democratic Republic were better integrated into the labor market than women of the former German Federal Republic where participation rates were low by international standards. After the unification of the two German states, the share of women resident in the area of the former German Democratic Republic (henceforth referred to as East Germany) who participated in the labor market declined, but only gradually. In May 2000, $72 \%$ of all women at working age in East Germany were employed or, if not, in search of employment. Although at that time the female participation rate in East Germany was considerably low compared to the one before unification, it still exceeded the corresponding rate of $62 \%$ for women resident in the area of the former German Federal Republic (henceforth referred to as West Germany) substantially.

The moderate decline in female labor force participation in East Germany is quite remarkable considering that women have been facing high levels of unemployment since the collapse of employment opportunities at the outset of unification. The economic transition following thereafter brought the employment rate among working age women to the West German level of $58 \%$. One might expect that enduring low outflow from unemployment to employment would discourage unemployed women from seeking employment. Besides, public policies during the economic transition, like early retirement schemes and the adaptation of the Western tax and transfer system, established incentives to withdraw from the labor market.

On the other hand, the central planners of the former East German command economy, in response to capital shortages, promoted female emancipation in the labor market. It is possible that this policy affected attitudes toward participation in the labor market fundamentally. If this is true, the question arises if East German women will adapt their behavior to West German patterns. For by definition unemployment is the difference between labor force participation and employment, an answer to this question might help to better understand the nature of the unemployment problem in East Germany. 
So far, most analysts of the Eastern European labor markets in transition, like Svejnar (1999) in a prominent survey, have largely ignored the role of labor force participation and labor supply. ${ }^{1}$ The aim of this paper is to address this gap, and to study empirically the adjustment of labor force participation behavior formed in a centrally planned economy and exposed to a free market economy. Reunited Germany provides a unique opportunity for this analysis, as it allows comparing the participation decisions of East German women to those of West German women who have been living with the same economic institutions.

For our analysis on the individual level, we will use regional samples of prime age non-single women, extracted from the 1990-1999 waves of the German Socio-Economic Panel. In view of the fact that shortage of job opportunities has played an important role during economic transition, we develop an empirical model that explains the incidence of employment as the result of (1) the individual choice to participate in the labor market and (2) the employment opportunities of those individuals who decide to participate. Estimation of this model lets us isolate the impact of differences in individual preferences, and of differences in individual and family characteristics, on the differences in participation levels.

On the basis of our empirical analysis we find that differences in preferences on participation largely explain the participation gap at the time of the unification. But afterward this factor has gradually become less important, which indicates that prime age East German women are indeed adjusting to the preference patterns of West German women. It turns out that, on the aggregate level, this process is partly offset by the individual characteristics of East German women, which have changed in a way favorable to participation.

The remainder of the paper is organized as follows: Section 2 sketches the impact of German unification on the East German labor market and describes the development of female labor force participation since unification on the aggregate level. Section 3 formulates our empirical model to jointly analyze employment and labor force participation on the individual level. Section 4 describes the data source - the German Socio-Economic Panel - and the sample that we extract. Section 5 discusses the estimation results and a variety of simulations providing a comparison between the behavior of East and West German women. Section 6 concludes.

\footnotetext{
${ }^{1}$ A recent exception is Boeri (2001) who incorporates labor supply in a model for Optimal Speed of Transition.
} 


\section{Labor Market Trends after Unification}

In this section, we describe some general trends of female labor force participation during the 1990s on the aggregate level. We first sketch the impact of unification on the East German labor market and discuss how the economic transition has affected the position of women. Next, we use data from the German Micro Census (GMC) to portray the differences in female labor force participation rates between East and West Germany in more detail. ${ }^{2}$

The unification of the two German states, in July 1990, from one day to another established the economic system of West Germany in East Germany. As part of the shock therapy, all contracts including wage agreements were converted into West German Marks at parity. The real price blow revealed the inefficient allocation of labor in the under-capitalized East German economy at once. The result was a sharp recession with production losses of about $50 \%$. In the process of privatizing state enterprises, employment contracted by about a third between 1990 and 1992. Since then the economy has recovered only very gradually. ${ }^{3}$

The recession hit employment among women harder than employment among men. By 1995, $36 \%$ of all employed women had lost employment, compared to only $23 \%$ of all employed men. One explanation for this outcome is that in case of lay-offs employers decided to discriminate against women (Meyer, 1997). A further explanation for the unequal outcome is based on selection. Using the 1990-1996 waves of the German Socio Economic Panel, Hunt (1999, 2001a) reveals that in the first years after unification low wage earners had a relatively high unemployment risk. This was a disadvantage for women who, at an average, earned somewhat lower wages than men. In the process of reallocating labor via the transitory state of unemployment, women had also less chances to be re-employed. In the period from 1992 to 1994, men took up net $90 \%$ of the new regular employment opportunities registered by the German Federal Labor Office (Gladisch and Trabert, 1995).

As a consequence of high lay-off rates combined with low re-employment rates, unemployment among East German women expanded rapidly at the early stages of the economic transition. In the GMC of 1993, a maximum of 18\% among East German women at working age without a job

\footnotetext{
2 The German Micro Census is an annual one percent rotary panel of the German population conducted by Statistics Germany. It is used to gather detailed information on socio-economic variables at the individual and household level, including records of labor market status (Statistics Germany, various issues). The GMC was first conducted in East Germany in April 1991.

${ }^{3}$ Cf. Lange and Pugh (1998) and Bonin and Zimmermann (2001) for surveys of the economic trends in East Germany since unification.
} 


\section{William Davidson Institute Working Paper 477}

declared seeking employment. Since then the East German economy has recovered somewhat, but the unemployment problem remains severe. In May 2000, 14.5\% of women at age 15-64 were in search of employment, more than ten percentage points above the West German rate of 4.4\%. At that time, the difference in male unemployment rates between East and West Germany was only 7.3 percentage points.

Nevertheless, the job prospects of East German women were perhaps not as bad as the customary focus on unemployment figures suggests. In contrast to experiences in other countries of Central and Eastern Europe studied by Boeri et al. (1998), it seems that in East Germany the reduction of the employment-population ratio was mild. In fact during the last decade the employment rate of East German women, despite a sharp decline in the aftermath of unification, mostly ranged above the Western level. From this perspective, it might look as if the permanence of high labor force participation would contribute to explaining the lasting unemployment problem of East German women.

An expectation among analysts (and policy makers) at the time of unification was perhaps that female labor force participation in the East would follow West German patterns soon. In fact, several arguments in favor of lower female participation rates in the post-communist labor market can be made. First of all, if the former full-employment policy put some pressure on East German women to work, they could now decide to withdraw from the labor market voluntarily, in favor of household production or leisure. Second, incentives that should drive women into employment ceased to exist with the unification. An important example is the reduction of childcare facilities, which forced women with dependent children to leave work at least in some Central and Eastern European countries (Chase, 1995).

At the same time, the extension of the West German economic system to East Germany introduced several labor supply disincentives. An example is the entitlement to long parental leave, which spurs detachment of mothers from the labor market (Gustafsson et al., 1996). Another example is the installation of Western income tax law in East Germany. The principle of full income splitting locks women in a family trap, as it imposes high marginal tax rates on second-earner wages. For West Germany, the negative impact on labor supply of married women is a well-established fact (Spahn et al., 1994; Strøm and Wagenhals, 1991). 
In view of the many labor supply disincentives, and the discouraging experience of constantly high unemployment, the share of East German women remaining in the labor market has been remarkably stable. This is evident from Figure 1, which shows the development by region of labor force participation rates, as contained in the GMC, for four different female cohorts who were at working age throughout the observation period. ${ }^{4}$ In East Germany, the labor force participation rates of prime-age (25-44) women fall steadily, but stay at levels above $90 \%$. Despite growing participation of prime-age women in the West (partly following cohort aging as Western mothers re-enter the labor force once their dependent children are old enough) the regional gap in the participation rates gets smaller only very gradually. It is still larger than 15 percentage points in 1999.

Also at the extremes of the age distribution, the participation rates of Eastern women do not adjust to Western levels. Interpreting the development of employment rates for the youngest and oldest generations (of age 15-24 and 45-55, respectively, at the time of the unification) one has to keep in mind that they are affected by the life-cycle: The participation levels of the youngest women increase as they gradually complete education, while the employment levels of the oldest women decrease as they gradually retire. For the oldest generation of East German women, the rates of participation in the labor market fall drastically over the observation period. Temporary early retirement schemes launched specifically to alleviate labor market pressure in the East are important for this development (Koller 1999). Considering the strong negative supply incentives introduced with these programs, and the bad employment prospects of older labor market participants, it is quite remarkable that the labor force participation rate of East German women in this generation continues to exceed that of West German women by around ten percentage points.

Perhaps labor supply within the youngest cohort of East German women is elevated at first by some peculiar attitudes toward education. As was shown by Dietrich (1999) on the basis of the European Labor Force Survey, East Germans continue to prefer vocational and apprenticeship training rather than attending university and therefore participate on the labor market earlier. But this cannot explain why the participation rate for this group exceed the Western level constantly

\footnotetext{
${ }^{4}$ The definition of the labor force of Statistics Germany, used for the GMC, includes all agents who have a work contract, including military personnel and apprentices, unpaid family workers, the self-employed, farmers and agents exercising a liberal profession. Besides, agents who claim to be in search of employment are considered as participating, and might be categorized as being involuntary unemployed.
} 


\section{William Davidson Institute Working Paper 477}

by about one fifth. This observation suggests that if anything, the labor supply of the youngest cohort will converge to that of prime age East German women, but not to that of the West German women of their own generation.

Giving little indication that female labor supply in East Germany would adjust to the new economic environment, Figure 1 poses an important question to answer if one wishes to fully understand the incidence of unemployment during the transition in the East: Why does the labor force participation rate of East German women rest at such a high level? Two hypotheses are worth our attention. The first and most obvious proposition is that the communist full employment policy shifted labor supply preferences of women permanently toward participation. The behavioral pattern might be strong enough to overcome the disincentives introduced with unification, and might even be carried over to young East-German generations. The second proposition is, however, that the differences in labor supply between East and West German women are largely the result of different individual and family characteristics, and wages, rather than the result of different preferences.

Some stylized facts may help to make the relevance of the second explanation conceivable. First, the fertility rate in East Germany dropped drastically immediately after unification, as a consequence of women postponing proliferation to a later age (Lechner, 1998). Therefore the employment disincentives of childcare facilities lacking might be less important in the East, an effect which is in line with the results presented by Hunt (1999). Second, a rather even distribution of wage earnings among husbands and wives, at least compared to West German couples, reduces the disincentives effected by the German income tax system. At the same time, women could not withdraw from the labor market without reducing the standard of living for their family substantially.

The relative importance of these rival explanations for persistent disparities of female labor force participation between East and West Germany is a question that can best be answered by an empirical investigation that accounts for individual and family characteristics together with wages. For this reason the next section formulates an empirical model for the labor force participation and employment opportunities of women on the individual level. 


\section{William Davidson Institute Working Paper 477}

\section{Empirical Model}

In this section we develop an empirical model to explain the incidence of labor force participation and employment. The underlying idea of the model will be that an individual has to take two hurdles to be employed: (1) she has to decide to participate in the labor market, and (2) she needs to have an employment opportunity. As the wage is a determinant of labor supply, and potentially also of labor demand, we extend the model to simultaneously explain wages. An important characteristic of our analysis is that we allow for gradual changes over time in the structure of labor supply preferences, employment opportunities, and wages.

Our model is a variation of the so-called double hurdle models of Cragg (1971) and Poirier (1980). It can also be viewed as an extension of the classical sample selection model of Heckman (1979). An example of a model similar to ours is Blundell et al. (1987) who estimates a joint model for labor supply, employment opportunities, and wages on the basis of the 1981 UK Family Expenditure Survey. Hujer and Grammig (1995) estimate another similar model on the basis of panel data extracted from the West German sample of the German Socio-Economic Panel and from the Michigan Panel Study of Income Dynamics.

A minor deviation from these references is that they consider labor supply in the form of working hours, where we study labor supply as a participation decision. A more substantial deviation from the references is related to the fact that they do not observably distinguish between voluntary and involuntary unemployment, but incorporate the two labor market states within the model on the basis of certain identifying assumptions. As a consequence, the predicted incidence of individual unemployment and non-participation might not match the corresponding trends on the macro level. As the latter are at the core of our interest, we decide to use an alternative approach, assuming that the different labor market states are directly observable. In order to distinguish between voluntary and involuntary unemployment, we will rely on survey data concerning involuntary unemployment.

To build our empirical model we first consider the participation decision. A woman will participate in the labor market if her market wage is larger than her reservation wage. We will treat this in reduced form similar to Gronau (1974). Define $P_{i t}{ }^{*}$ as a latent variable for labor force participation, and define $P_{i t}$ as the observed outcome on labor force participation, both for woman $i$ at time $t$. Define $X^{P}{ }_{i t}$ as a vector of individual labor supply characteristics, and define $w_{i t}{ }^{*}$ as the 
logarithm of the gross market wage of woman $i$ at time $t$. Then we formulate the participation hurdle to employment as follows:

$$
\begin{gathered}
P_{i t}{ }^{*}=X^{P}{ }_{i t} \beta_{t}{ }^{P}+w_{i t}{ }^{*} \gamma_{t}{ }^{P}+\varepsilon^{P}{ }_{i}+\varepsilon^{P}{ }_{i t} \\
P_{i t}=1 \quad \text { if } P_{i t}{ }^{*}>0 \\
0 \quad \text { if } P_{i t}{ }^{*} \leq 0
\end{gathered}
$$

(does participate)

(does not participate)

with $\beta_{t}^{P}$ a vector of parameters, $\gamma_{t}^{P}$ a parameter, and $\varepsilon^{P}{ }_{i}$ and $\varepsilon^{P}{ }_{i t}$ an individual specific and a remainder error term, respectively.

A non-standard feature of our model is that it allows the parameters to depend on time. The underlying idea is to incorporate behavioral changes, which we expect to observe especially for East German women who need to adjust to a new economic and social environment. The most general option would be to allow for different parameters in each year, but this might lead to sequences of parameters difficult to interpret. Instead, we restrict the variation of the parameters to a cubic time pattern. More specifically, we assume that

$$
\beta_{t}^{P}=\beta_{0}^{P}+\beta_{1}^{P} t+\beta_{2}^{P} t^{2} \quad ; \quad \gamma_{t}^{P}=\gamma_{0}^{P}+\gamma_{1}^{P} t+\gamma_{2}^{P} t^{2}
$$

where $t$ measures time since German unification.

To describe the second hurdle to employment, we assume that a woman who is willing to participate in the labor market will be observed in employment if she has an employment opportunity. Parallel to Blundell et al. (1987), the employment opportunity equation should be interpreted as being a reduced form: It does not represent explicitly a lay-off rate or job arrival rate. Define $E_{i t}{ }^{*}$ as a latent variable for having an employment opportunity, and define $E_{i t}$ as the observed outcome on having an employment opportunity for woman $i$ at time $t$. Next define $X^{E}{ }_{i t}$ as a vector of characteristics impacting on employment. Then we describe the employment hurdle by:

$$
\begin{aligned}
& E_{i t}{ }^{*}=X^{E}{ }_{i t} \beta_{t}^{E}+\gamma_{t}^{E} w_{i t}{ }^{*}+\varepsilon^{E}{ }_{i}+\varepsilon^{E}{ }_{i t} \\
& E_{i t}=1 \quad \text { if } E_{i t}{ }^{*}>0 \\
& 0 \quad \text { if } E_{i t}{ }^{*} \leq 0
\end{aligned}
$$

(has employment opportunity)

(has no employment opportunity)

with $\beta_{t}^{E}$ a vector of parameters, $\gamma_{t}^{E}$ a parameter, and $\varepsilon^{E}{ }_{i}$ and $\varepsilon^{E}{ }_{i t}$ an individual specific and a remainder error term, respectively. As the earnings capacity of an individual is generally related 


\section{William Davidson Institute Working Paper 477}

to her labor market prospects, we allow the market wage $w_{i t}{ }^{*}$ of woman $i$ at time $t$ to have a direct impact on the probability of having an employment opportunity. Parallel to the participation hurdle, parameters are permitted to vary along a cubic pattern to design the changing employment conditions faced in particular by East German women.

To complete the model, we note that the market wage $w_{i t}{ }^{*}$ is measured only for women who take the two hurdles. Thus we need to model wages simultaneously. Define $Z_{i t}$ as a vector of individual wage characteristics. Then we formulate the wage equation as follows:

$$
\begin{array}{lll}
w_{i t}{ }^{*}=Z_{i t} \delta_{t}+v_{i}+v_{i t} & & \\
w_{i t}=w_{i t}{ }^{*} & \text { if } P_{i}{ }^{*}>0 \text { and } E_{i}{ }^{*}>0 & \text { (wage observed) } \\
\text { missing } & \text { if } P_{i}{ }^{*} \leq 0 \text { or } E_{i}{ }^{*} \leq 0 & \text { (wage not observed) }
\end{array}
$$

with $\delta_{t}$ a vector of parameters, again treated as time-variant, and $v_{i}$ and $v_{i t}$ an individual specific and a remainder error term, respectively.

To summarize, we distinguish three labor market outcomes:

1. Employment:

2. Involuntary unemployment:

3. Voluntary unemployment:

$$
\left(P_{i t}=1, E_{i t}=1, w_{i t}=w_{i t}{ }^{*}\right)
$$$$
\left(P_{i t}=1, E_{i t}=0, w_{i t}=.\right)
$$

$$
\left(P_{i t}=0, E_{i t}=., w_{i t}=.\right)
$$

The probability that a woman is observed as being employed is given by the probability that she participates and at the same time has an employment opportunity $\left(P_{i t}=1, E_{i t}=1\right)$. Only in this case we observe her market wage. A woman might also be unemployed involuntarily. The probability of this outcome is given by the probability that she participates combined with the probability that she does not have an employment opportunity $\left(P_{i t}=1, E_{i t}=0\right)$. Finally, a woman can be unemployed voluntarily. The probability of this outcome is given by the probability that she decides against labor market participation $\left(P_{i t}=0\right)$.

A potential problem of the approach is misspecification due to misclassification. On the one hand, some of the non-participants might be discouraged workers, while on the other hand some of the involuntary unemployed might only register as being unemployed to retain certain rights on welfare and other social benefits. To our knowledge, only one recent study has taken such considerations into account; Blundell et al. (1998) allow for discouraged workers by exploiting 
data on involuntary unemployment in the U.K. Family Expenditure Survey. We will not allow for misclassification, as it would be cumbersome to integrate in our model.

A crucial issue of our empirical model is identification, which is somewhat different from the standard double hurdle models referred to at the beginning of this Section. Appendix A describes the exclusion restrictions we need to impose. In particular, we require at least one exogenous variable specific to the participation equation, and one specific to the employment opportunity equation. Hence, in the empirical section, we assume that certain individual and family characteristics affect participation only, and that certain regional labor market characteristics affect employment opportunities only. In this, we follow a tradition in the labor supply literature, where identification without assumptions on exclusion restrictions is difficult.

Combining the probabilities for the three possible labor market outcomes yields the likelihood for women $i$ at time $t$ :

$$
\Lambda_{i t}=\Pi_{1} P\left(P_{i t}=1, E_{i t}=1 \mid w_{i t}\right) f\left(w_{i t}\right) \Pi_{2} P\left(P_{i t}=1, E_{i t}=0\right) \Pi_{3} P\left(P_{i t}=0\right)
$$

To estimate this discrete choice panel data model, we will choose a random effects model specification. The details of our estimation strategy are discussed in Appendix B.

\section{Data}

The data we use for our empirical analysis is taken from the 1990-1999 waves of the German Socio-Economic Panel (GSOEP). ${ }^{5}$ The GSOEP contains a separate panel of households who were resident in East Germany shortly before the unification (the so-called sample C). We will categorize the members of this sample as East Germans even if they moved to live in West Germany during the observation period, or commuted to be employed in West Germany. In the same fashion, the sample of West Germans is composed of households who initially lived in the German Federal Republic (the so-called sample A). ${ }^{6}$

For both regions we select a sample of women with a labor market record that allows us to determine their labor market status. Due to limitations of the GSOEP, the concepts of labor market status that we use from now on are somewhat different from the official definitions of

\footnotetext{
${ }^{5}$ See Burkhauser et al. (1997) for a general introduction to the GSOEP.

${ }^{6}$ The samples do not include households with a foreign head. For a regional comparison the under-sampling of foreigners is an advantage: We expect foreigners to exhibit a different labor supply behavior, while the share of foreigners is lower in East than in West Germany.
} 


\section{William Davidson Institute Working Paper 477}

employment and labor force participation underlying the figures previously reported. More specifically, we will count individuals observed with positive working hours as employed. This is not very different from the official concept, which is also not limited to dependent employment. Labor force participation, by definition, comprises employment and involuntary unemployment. On the basis of the GSOEP, we can define involuntary unemployment only as being registered unemployed. This means a clear deviation from the official concept of labor force participation based on individual job search.

For several reasons we limit the analysis to women who were between 25-44 years old at the time of unification. First, our empirical model is not very well designed to study older agents who have an outside option of early retirement. As was discussed above, early retirement policies had a strong impact on the employment and participation rates in East Germany, but work disincentives stemming from the design of Social Security are also influential in West Germany (Börsch-Supan and Schmidt, 2001). Regarding the youngest generation who entered the labor market only after unification, we believe that region specific selection into and out of education would be an important issue biasing the parameters of our model.

Concerning the two middle-aged cohorts, analyzed separately above, we lump them together in order to increase sample sizes. It is evident from Figure 1 that the labor force participation patterns of these cohorts are quite similar so that it makes good sense to study them jointly. The employment and labor force participation rates derived from the GSOEP and the GMC match remarkably well. For the West German sample, the differences between the two data sources are never statistically significant. For the East German sample, aggregate employment rates are not significantly different except for 1991, but throughout the observation period labor force participation rates according to the GSOEP are significantly smaller. This suggests that in East Germany the number of women who are registered unemployed could be smaller than the number of women who are in search of employment. Still the trends in aggregate labor force participation indicated by the GSOEP and the GMC are clearly parallel. Hence we believe that using information on registered unemployment is a reasonable alternative to using data on search behavior, so that the GSOEP is suitable for our purposes.

For the empirical analysis, we reduce the two samples to include married and cohabiting women only. The reason to focus on women who have a partner is that the labor supply behavior of single women is rather similar by region. Also in West Germany, women who are single 
normally stay closely attached to the labor market. A straightforward decomposition of the regional labor force participation gap, into the parts explained by single women, by married or cohabiting women, and by differences in marriage or cohabiting rates, allows us to quantify this argument: ${ }^{7}$ Almost $90 \%$ of the participation gap found for prime age women in the GSOEP is attributable to the different labor market attachment of married or cohabiting women in East and West Germany. Only the remainder is attributable to single women, as the explanatory power of differences in marriage or cohabiting rates is about zero.

After removing women with missing values, we are left with 750 to 900 observations per year of West German women, and with 540 to 770 observations per year of East German women. Table 1 displays the sample statistics for the variables of interest. Concerning labor market status, our samples clearly capture the weakly increasing participation and employment trends in West Germany, whereas the employment levels of the East German women, after the initial sharp decline, are stable and above those in the West. Participation quotas of East German women are somewhat decreasing, but remain high.

The substantial disparities in wages and family characteristics between East and West German women that emerge from Table 1 might help to explain the different regional participation patterns. Under communism, East German women typically gave birth to children at a young age. Total fertility was higher than in the West, but dropped substantially with the unification. The consequences of this are reflected in Table 1: Prime-age East German women, relative to the West, have more dependent children at school age. At the same time, the average number of children at pre-school age, especially of children born after unification (age 0-2), is much lower in the East. Thus, if lack of childcare facilities for children not yet at school were a disincentive for mothers to work, we would expect East German women to participate in the labor market more frequently by comparison.

Another fact that is derived from Table 1 is substantial regional disparity in real wages, which we calculate in hourly terms on the basis of gross earnings in the month prior to the interview, in combination

\footnotetext{
${ }^{7}$ Define $L F P_{R}$ as the labor force participation rate in region $R$ (east versus west), $L F P_{R}^{X}$ as the labor force participation rate in region $R$ and marriage and cohabiting status $X$ (single versus married or cohabiting), and $M_{R}$ as the marriage and cohabiting rate in region $R$. Then it is possible to disentangle the regional difference in the labor force participation rates in the following way:
}

$$
L F P_{E}-L F P_{W}=\underbrace{M_{W}\left(L F P_{E}^{M}-L F P_{W}^{M}\right)}_{\text {Married Women }}+\underbrace{\left(1-M_{W}\right)\left(L F P_{E}^{S}-L F P_{W}^{S}\right)}_{\text {SingleWomen }}+\underbrace{\left(M_{W}-M_{E}\right)\left(L F P_{E}^{S}-L F P_{E}^{M}\right)}_{\text {Marriage Rate }}
$$


with the standard working hours of an individual. Despite the possibility of noise in the variable on hours, we prefer the hourly wage to the monthly wage, to account for the fact that there are sizeable regional differences in average working hours. We deflate wages according to area of residency, and establish equal purchasing power by relying on Grunert (2000) who finds that in 1998 price levels were $10 \%$ lower in the East than in the West, to correct nominal values for East Germany.

As expected, real wages of East German women, at the time of unification, were substantially lower than real wages of West German women. But those who stayed employed experienced substantial wage growth afterwards. Although convergence of wages has slowed down since 1995, the regional gap in female hourly wages, in our samples, has become less than $10 \%$ in recent years. In contrast, the real wages of partners in East Germany are still much lower than those of their Western countrymen, lagging behind by roughly one third. Since unemployment benefits are paid in proportion to previous income in Germany, also the average amount of benefits received by a partner who is unemployed is substantially smaller in the East.

These observations could provide an explanation for the high participation rates of married wives. East German women might not have the possibility to withdraw from the labor market, since their earnings are needed to guarantee a certain standard of living for the family. In this regard, it is perhaps revealing that the elevated employment rates of East German wives just compensate the (judged by West German standard) high incidence of unemployment among their husbands. At least, while on average 1.57 members of a West German couple were employed in 1999, this figure was 1.58 in East Germany. 


\section{William Davidson Institute Working Paper 477}

\section{Empirical Results}

This section presents the estimation results for the model developed in Section 3, based on the regional samples of married and cohabiting women discussed in Section 4. We will first discuss the results for East German women, then for West German women, and finally we present simulations illustrating the importance of preferences and of individual characteristics for the different labor market attachment of East and West German women. The estimation results presented in this section are the result of a trade off between efficiency (in terms of the variances) and flexibility of the model. As the empirical model has a large number of parameters, especially due to the interactions with time since unification, we eliminate many insignificant variables.

\section{East German Sample}

Table 2 shows the estimation results for the participation and the employment opportunity equations in the East German sample of prime-aged women, together with the outcome of the supporting wage equation. The estimation results for the latter are in harmony with what is known about the development of Eastern post-unification wages, described, for example, by Franz and Steiner (2000). In particular, the coefficients of the year dummies indicate both the large wage increase at the initial stage of the economic transition, consequent to a policy of equal pay established through collective bargains, and the moderation of wage growth when the transformation crisis became perceived as being permanent. Our estimation results even indicate that wage growth, in real terms, came to an end after 1995.

Within our analysis the wage equation is of auxiliary interest. We need it to predict the wages of the non-employed. For this reason we keep the impact of education levels flexible by interacting them with age. We decide to avoid standard explanatory variables like tenure or experience. In view of high employment under communism, the large disparity in tenure and experience of East and West German women would make a regional comparison difficult. Although the coefficients on education are mostly insignificant (in part due to the interaction with age), they turn out to be broadly consistent with estimates based on the GSOEP provided by Hunt (2001b). Taking into account the interactions with age, the estimated coefficients suggest that relative to apprenticeship, which is the omitted category, vocational training and university education are more highly rewarded. The interaction of the education levels with time since unification also replicates the result by Hunt that wages in the highest skill group were rising relatively faster as 


\section{William Davidson Institute Working Paper 477}

the economic transformation progressed. Finally, the results exhibit the expected decreasing returns to age.

The medium column of Table 2 summarizes the results for the employment opportunity equation. The derived latent market wage has a significant positive impact on the chances of having an employment opportunity, which is in line with the hypothesis that women with a higher earnings capacity have a better chance to be employed. Furthermore the impact of wages increased over time. This finding is in line with earlier results on the employment and unemployment durations of East German women based on the GSOEP, reported by Hunt (1999). Furthermore in East Germany, age does not appear to have an impact on the individual employment opportunity probability, at least not in our medium age range.

Besides personal characteristics, also the tightness of the regional labor market has an impact on the employment opportunity probability. In general this natural connection is difficult to confirm, but we observe that the local unemployment level, as reported by the Labor Offices, has indeed a negative impact on the employment opportunity probability for East German women. The regional vacancy rate, on the other hand, exerts no separate influence. Judged by the coefficient on the time dummies, the employment opportunity probabilities faced by East German women declined significantly over time, which is consistent with the emergence of high unemployment rates in the East.

We now come to the results for individual labor market participation at the core of our interest. According to the first column of Table 2, particularly two factors are relevant for the participation decision of the East German women. First, as one would expect, participation varies inversely with the number of young children present in the household. But the disincentive effect of children seems to disappear once children reach school age. The negative sign of the interaction between the number of children aged 3-5 and the time since unification implies that the disincentive effect increased over time. An appealing explanation is that this is due to the decline of childcare facilities in the East, as this could have forced women to withdraw from the labor market.

Second, the own wage capacity has a highly significant positive impact on participation. This is obviously in line with the economic theory on reservation wages. The interaction of wage and time since unification is excluded from the model, as it is insignificant. The income of the partner 
present in the household has no significant impact on female participation. This is true whether the partner is employed (and receives a positive hourly wage) or unemployed (and receives a positive monthly benefit). One interpretation of this is that East German women decide about labor force participation independently.

The results for the East German sample provide no simple evidence that women would reduce participation to the lower Western levels. At least there is no independent negative time trend in the probability of labor force participation. However, interacted with age and the number of children, time since unification is significantly different from zero. This suggests that at least certain behavioral changes affected participation rates during the observational period.

Table 3 reports the estimated variances and covariances of the participation and employment opportunity equations, and of the supporting wage equation. The results for the East German sample are on display in the upper part. We find evidence for an individual specific effect in the employment opportunity probability as well as in the participation probability. But the correlations between the errors terms of the two equations are not significant, which suggests there are no unobserved individual characteristics affecting both outcomes. Other correlations are not identified, as is explained in Appendix A.

\section{West German Sample}

The estimation results for the West German women are presented in Table 4. The wage regression in the last column captures the period of moderate real wage growth that sets West Germany apart from what was experienced in East Germany after unification. Most of the variables on education are insignificant, which is the result of including interaction terms with age. We maintain them in the empirical model nevertheless, to keep the estimation results for the East and West German women comparable.

In the employment opportunity equation, in contrast to the results for East German women, the wage and time effects do not have explanatory power. Also the macro measures for labor market tightness are insignificant. This somewhat implausible finding contrasts the empirical evidence on employment chances of West German women provided by Hujer and Grammig (1995) whose analysis is founded on regionally more disaggregated data, however.

The estimation results on female labor force participation derived from the Western sample reveal important differences in comparison to the Eastern sample. Regarding the number of 
dependents, for West German women also children at school age seem to create a disincentive to participate. This is in line with the fact that Western women, at least in the cohort under study, after childbirth still often withdraw from the labor market permanently. Further, while the chance to be in the labor market is naturally positively related to their own wage, it appears that for West German women the participation decision interacts also with the income of their partner. His wage if employed, or, alternatively, the level of his benefit, relates negatively to the female participation rate. This result fits the observation that many married women in West Germany are second earners.

The lower part of Table 3 reports the estimated variances and covariances of the model for the West German sample. There is evidence for an individual specific effect in the participation probability, but not in the employment opportunity probability. The covariances of the participation and employment opportunity equations are again insignificant. Thus there is no evidence that unobserved characteristics of West German women have an impact on both labor market outcomes.

\section{Simulations}

The magnitude of the disparities in behavior between East and West German women is difficult to judge by simply comparing the estimated parameters. First, the reported estimates do not measure marginal effects. Moreover, the models we estimate on the basis of the East and West German samples do not contain exactly the same set of variables, since our model for West German women excludes most of the time effects that we consider relevant for East German women in view of the economic transition process. Therefore we rely on simulations to bring out the effects of the estimated parameters on labor force participation. For a reference, we apply the estimated parameter for our samples of East and West German women to their observed characteristics. Figure 2 shows that the outcome of the basis simulation is similar to the actual pattern of female participation rates on the aggregate level. This suggests that at least our empirical model satisfactorily replicates the data.

In a first experiment, actually not included in Figure 2, we eliminate the impact of the time passed since unification on the labor force participation rates. Without time effects, compared to the basis simulation, the participation rate of East German women increases over time, reaching a level close to full participation by the end of the decade. This result shows that actually there 
exists an independent time trend impacting negatively on participation in the East. The fact that the participation rates observed in East Germany were stable after unification despite the negative time trend shows that other developments influenced labor supply positively. The major positive factor appears to be the large real wage increase for women. Choosing leisure (or home production) has become more expensive, and therefore less attractive. Note that the impact of increasing wages in the participation equation is not offset by an interaction between wages and time since unification, as this interaction is completely insignificant and therefore eliminated from the estimated model.

Next, we analyze what part of the participation gap between East and West German women is caused by regional differences in individual labor supply preferences (as indicated by the estimated parameters of the participation equation), and what part is explained by differences in individual characteristics observed in our samples. We run two counterfactual experiments: (1) a preference simulation, which applies the behavioral parameters estimated on the basis of the Western (Eastern) sample to the individual characteristics of East German (West German) women, and (2) a characteristics simulation, which applies the individual characteristics of West German (East German) women to the behavioral parameters estimated on the basis of the Eastern (Western) sample. ${ }^{8}$

For East German women, the preference simulation generates much lower participation rates. We observe that if East German women had adapted their labor supply preferences to those prevalent among West German women, the regional participation gap had largely vanished at least for the first years after unification. This implies that mostly differences in preferences, and not differences in individual characteristics, bring about the distinct participation patterns on the Eastern and Western labor markets. However, it turns out that the influence of specific Eastern labor supply preferences is in decline. In the East German chart of Figure 2, the labor force participation gap predicted by the East German and the West German parameters, respectively, clearly becomes smaller over time.

On the other hand, the characteristics simulation reveals that emerging regional disparities in individual characteristics are widening the participation gap between East and West Germany. At

\footnotetext{
${ }^{8}$ In the characteristics simulation, we change all individual variables with the exception of the derived latent wage. Incorporating the wage gap between East and West German women blurs the effects of regional disparity in characteristics that we seek to isolate.
} 
the time of unification, given the labor supply preferences of East German women, exchanging individual characteristics by region would have hardly affected the level of labor force participation. Over the years, however, we observe that East German women participate less frequently, if we endow them with Western characteristics. The main factor explaining this result is that prime age East German women now have much fewer small children by comparison.

The results of the preference and characteristics simulations for the West German women are on display in the second chart of Figure 2. The results and interpretations are parallel: It turns out that specific regional attitudes to labor supply, which could fully explain the differences in participation rates between East and West Germany, have become less important during the 1990s. At the same time, the individual characteristics of East German women have changed in a way favorable to labor supply. This process partly offsets the impact of adjusting labor supply behavior, and prevents more rapid convergence of the regional participation patterns.

\section{Summary and Concluding Remarks}

The aim of this paper was to analyze the determinants of preferences on labor force participation by East German women after German unification. As the establishment of the West German economic system in East Germany among other things raised marginal tax rates on second earner incomes and reduced childcare facilities, the persistence of high female participation rates is a somewhat unexpected fact. A natural explanation would be that simply being exposed to a free market economy did not change the preferences of East German women formed under communism. But the leap of real wages, and the changing individual and family characteristics of East German women after the unification might provide a different explanation.

To disentangle the impact of preferences from that of changing individual characteristics, and wages, we developed an empirical model that simultaneously explains individual labor force participation, employment opportunities and wages. For the estimation of the model, East and West German samples of prime-aged married (or cohabiting) women were taken from the 19911999 waves of the German Socio-Economic Panel.

The estimated parameters indicate that the specific preferences on labor force participation of East German women could indeed explain the substantial difference in female participation rates between East and West Germany observed at the time of the unification. Afterwards, however, the behavior of East German women has changed in the sense that older women and women with 
children at pre-school age have become less willing to participate. The reason why the significant change in individual preferences on participation is not observed on the aggregate level is that it is partly offset by individual characteristics that have changed in a way favorable to participation. In particular, a reduced number of small children in the consequence of fertility decline, and also the increased real wages available to East German women who manage to stay employed, promoted female participation after unification.

The reunification of Germany can be viewed as a unique experiment, as in no other country economic transition could be implemented so immediately and radically as in East Germany. The data generated by this process provide us with the exceptional opportunity to study behavioral adjustment after the exposure to a free market system. In this paper, we had to limit the analysis to preferences on labor force participation within a certain age group, but it is easy to come up with extensions for future research.

As the participation decision captures only one aspect of labor supply behavior, an obvious issue to study next would be the decision on working hours. It is not only a fact that labor force participation of East German women continues to be high, but also that East German women who are employed continue to work, on average, substantially more hours than West German women. Another issue of interest would be the labor supply of East German cohorts entering the labor market only after unification. The participation rates of younger East German women observed so far seem to suggest that their participation rates will not develop parallel to that of West German women in their generation. Does this mean that labor supply behavior of East Germans will permanently stay different? To answer the question adequately, one will have to wait until the behavior of younger generations gets fully exposed to the labor market. 


\section{Appendix A: Identification}

Due to the fact that the model of Section 3 deviates from the classical sample selection model, identification is not straightforward. This appendix discusses the assumptions we make to identify and estimate the model. Our first postulate is:

(A.1) The vectors of individual specific error terms $\left(\varepsilon_{i}^{P}, \varepsilon_{i}^{E}, v_{i}\right)$ and the remainder error terms $\left(\varepsilon^{P}{ }_{i t}, \varepsilon_{i t}^{E}, v_{i t}\right)$ are i.i.d. multivariate normally distributed.

This assumption implies that we take a random effects approach, which means that we assume the individual effects to be uncorrelated with the exogenous variables. An alternative would be to suppose fixed effects. However, this approach is difficult to apply for the given system of equations, and is therefore beyond the scope of this study.

Strictly speaking, our model would be identified on the basis of the normality assumption only. But we consider identification on the basis of distributional assumptions only not to be very satisfactory. Therefore, we choose to impose exclusion restrictions:

(A.2) There will be at least one exogenous variable specific to the participation equation, and one to the job-offer equation.

The fact that we observe whether a woman is voluntarily or involuntarily unemployed does not mean that we only need one exclusion restriction. To see this impose two simplifications that do not affect identification: ignore the panel aspect of the data, and transform the model into a reduced form model by imposing $\gamma^{P}=0$ and $\gamma^{E}=0$. Now define $\sigma_{v P}=\operatorname{cov}\left(\varepsilon_{i}^{P}, v_{i}\right)$ and $\sigma_{v E}=\operatorname{cov}\left(\varepsilon^{E}{ }_{i}, v_{i}\right)$. Then the expected wage of the employed is given by

$$
\begin{aligned}
E\left(w_{i} \mid P_{i}=1, E_{i}=1\right) & =Z_{i} \delta+E\left(v_{i} \mid P_{i}=1, E_{i}=1\right) \\
& =Z_{i} \delta+\sigma_{v P} M_{P E}\left(X^{P}{ }_{i} \beta^{P}, X^{E}{ }_{i} \beta^{E}\right)+\sigma_{v E} M_{E P}\left(X^{P}{ }_{i} \beta^{P}, X^{E}{ }_{i} \beta^{E}\right),
\end{aligned}
$$

where $M_{P E}$ and $M_{E P}$ are defined parallel to Maddala (1983, Section 9.6).

The first point to note is that one exclusion restriction is sufficient to guarantee that the tuple $\left(M_{P E}, M_{E P}\right)$ and $Z_{i}$ are not multi-collinear. Furthermore, the event $M_{P E}=M_{E P}$ has probability zero. This implies that in a two-step estimation procedure, where the parameters $\left(\beta^{P}, \beta^{E}\right)$ are estimated in the first round, the parameters $\left(\sigma_{v P}, \sigma_{v E}\right)$ would be identified in the second round. But in this two-step estimation procedure the identification of the parameters $\left(\beta^{P}, \beta^{E}\right)$ is not straightforward, 
as the outcome on the employment opportunity is observed only conditional on participation. This introduces another sample selection problem, and proper identification of the employment opportunity parameters requires an exogenous variable that is excluded from the employment opportunity equation, and that is specific to the participation equation.

To conclude the argument, note the possibility that the error terms of the participation and the employment opportunity equation $\left(\varepsilon^{P}{ }_{i}, \varepsilon^{E}{ }_{i}\right)$ are uncorrelated. This would imply

(A.4) $M_{P E}\left(X^{P}{ }_{i} \beta^{P}, X^{E}{ }_{i} \beta^{E}\right)=\lambda\left(X^{P}{ }_{i} \beta^{P}\right) \quad ; \quad M_{E P}\left(X^{P}{ }_{i} \beta^{P}, X^{E}{ }_{i} \beta^{E}\right)=\lambda\left(X^{E}{ }_{i} \beta^{E}\right)$,

with $\lambda($.) being the classical Heckman's sample selection term, which is the inverse Mill's ratio. So to guarantee identification in equation (A.3), separate exclusion restrictions are necessary for the participation and the employment opportunity equation.

A last issue concerns the identification of the covariances. In the classical sample selection model, the participation equation does not contain the wage itself. Since both the wage and the participation equation will contain unobserved variables impacting on wages, one would generally expect that the error terms to be correlated. In our structural model incorporating the wage in the participation and the employment opportunity equation, this correlation is fully exhausted by the identification of the wage parameters $\left(\gamma^{P}, \gamma^{E}\right)$. As a consequence, any additional parameters in the form of covariances between the error terms of the wage equation $\left(v_{i}, v_{i t}\right)$ cannot be identified. We hence make the assumption that
(A.5)
$\operatorname{Cov}\left(\varepsilon_{i}^{A}, v_{i}\right)=0 \quad ; \quad \operatorname{Cov}\left(\varepsilon_{i t}^{A}, v_{i t}\right)=0$
for $A=P, E$. 


\section{Appendix B: Estimation Procedure}

The estimation strategy we use in this paper is simulated maximum likelihood. The likelihood contribution of an employed woman $i$ at time $t$ takes the following form:

$$
\text { (B.1) } \begin{aligned}
\Lambda_{i t} & =P\left(P_{i t}=1, E_{i t}=1 \mid w_{i t}\right) f\left(w_{i t}\right) \\
& =P\left(P_{i t}{ }^{*}>0, E_{i t}{ }^{*}>0 \mid w_{i t}\right) f\left(w_{i t}\right) \\
& =\iiint P\left(\varepsilon^{P}{ }_{i t}>., \varepsilon^{E}{ }_{i t}>. \mid \varepsilon^{P}{ }_{i}, \varepsilon^{E}{ }_{i}, v_{i}\right) p\left(v_{i t}=. \mid v_{i}\right) p\left(\varepsilon^{P}{ }_{i}, \varepsilon^{E}{ }_{i}, v_{i}\right) d \varepsilon^{P}{ }_{i} d \varepsilon^{E}{ }_{i} d v_{i}
\end{aligned}
$$

To avoid more dimensional numerical integration, we approximate the integral by a simulated mean: For each individual we take $\mathrm{R}$ drawings from the distribution of the error-terms, and compute the average of the $\mathrm{R}$ likelihood values conditional on the drawn errors. Provided that $\mathrm{R}$ converges to infinity with the number of observations fast enough, this method is asymptotically equivalent to exact maximum likelihood. See, for example, Gourieroux and Montfort (1993). The simulated form of this part of the likelihood is

$$
\text { (B.2) } \Lambda_{i t}{ }^{s} \quad=(1 / R) \sum_{r=1, \ldots, R} P\left(\varepsilon_{i t}^{P}>., \varepsilon_{i t}^{E}>. \mid \varepsilon^{P}{ }_{i r}, \varepsilon^{E}{ }_{i r}, v_{i r}\right) p\left(v_{i t}=. \mid v_{i r}\right)
$$

The error terms $\left(\varepsilon_{i r}^{P}, \varepsilon_{i r}^{E}, v_{i r}\right)$ of the simulated likelihood are random draws from the multivariate normal distribution.

The likelihood contribution of a woman $i$ involuntary unemployed at time $t$ is given by:

$$
\text { (B.3) } \begin{aligned}
\Lambda_{i t} & =P\left(P_{i t}=1, E_{i t}=0\right) \\
& =\iiint P\left(\varepsilon^{P}{ }_{i t}-\gamma^{P} v_{i t}>., \varepsilon^{E}{ }_{i t}-\gamma^{E} v_{i t}<. \mid \varepsilon^{P}{ }_{i}, \varepsilon^{E}{ }_{i}, v_{i}\right) p\left(\varepsilon^{P}{ }_{i}, \varepsilon^{E}{ }_{i}, v_{i}\right) d \varepsilon^{P}{ }_{i} d \varepsilon^{E}{ }_{i} d v_{i} \\
& =\iiint \int P\left(\varepsilon^{P}{ }_{i t}>., \varepsilon^{E}{ }_{i t}<. \mid \varepsilon^{P}{ }_{i}, \varepsilon^{E}{ }_{i}, v_{i}, v_{i t}\right) p\left(\varepsilon^{P}{ }_{i}, \varepsilon^{E}{ }_{i}, v_{i}\right) p\left(v_{i t}\right) d \varepsilon^{P}{ }_{i} d \varepsilon^{E}{ }_{i} d v_{i} d v_{i t}
\end{aligned}
$$

The simulation of this part of the likelihood is done in the same fashion as for equation (B.1). The only substantial difference is that we now also need to simulate the error-term $v_{i t}$. The simulated likelihood reads as:

(B.4) $\Lambda_{i t}{ }^{s} \quad=(1 / R) \sum_{r=1, . ., R} P\left(\varepsilon_{i t}^{I}>., \varepsilon^{P}{ }_{i t}<. \mid \varepsilon^{P}{ }_{i r}, \varepsilon^{E}{ }_{i r}, v_{i r}, v_{i t r}\right)$

where the error terms $\left(\varepsilon_{i r}^{P}, \varepsilon_{i r}^{E}, v_{i r}\right)$ are random draws from the multivariate normal distribution, and $v_{i t r}$ random draws from the univariate normal distribution.

Finally, the likelihood contribution of a non-participating, i.e., voluntary unemployed, woman is:

(B.5) $\Lambda_{i t}=P\left(P_{i t}=0\right)$ 
William Davidson Institute Working Paper 477

$$
=\iint P\left(\varepsilon_{i t}^{P}-\gamma^{P} v_{i t}>. \mid \varepsilon_{i}^{P}, v_{i}\right) p\left(\varepsilon_{i}^{P}, v_{i}\right) d \varepsilon_{i}^{P} d v_{i}
$$

where the distribution of the term $\left(\varepsilon^{P}{ }_{i t}-\gamma^{P} v_{i t}>\right.$.) is straightforward due to assumption (A.3), stated in the Appendix A. The simulated form of the likelihood is given by:

(B.6) $\Lambda_{i t}{ }^{s}=(1 / R) \sum_{r=1, \ldots, R} P\left(\varepsilon^{P}{ }_{i t}-\gamma^{P} v_{i t}>. \mid \varepsilon^{P}{ }_{i r}, v_{i r}\right)$

Again, the error terms $\left(\varepsilon_{i r}^{P}, v_{i r}\right)$ are random draws from the multivariate normal distribution. 


\section{William Davidson Institute Working Paper 477}

\section{References}

Blundell, R., J. Ham, and C. Meghir (1987), Unemployment and Female Labour Supply, Economic Journal, Vol. 97, pp. 44-64.

Blundell, R., J. Ham, and C. Meghir (1998), Unemployment, Discouraged Workers, and Female Labour Supply, Research in Economics, Vol. 52, pp. 103-131.

Boeri, T. (2001), Transition with Labour Supply, IZA Discussion Paper No. 257, Bonn.

Boeri, T., M. Burda and J. Köllo (1998), Mediating the Transition: Labour Markets in Central and Eastern Europe, CEPR, London.

Börsch-Supan, A. and P. Schmidt (2001), Early Retirement in East and West Germany, in: R. Riphahn, D. Snower and K. F. Zimmermann (eds.), Employment Policy in Transition, The Lessons of German Integration for the Labor Market, Berlin: Springer, pp. 83-102.

Bonin, H. and K. F. Zimmermann (2001), The Post-Unification German Labor Market, in: R.T. Riphahn, D.J. Snower and K. F. Zimmermann (eds.), Employment Policy in Transition, The Lessons of German Integration for the Labor Market, Berlin: Springer, pp. 8-30.

Burkhauser, R., M. Kreyenfeld, and G. Wagner (1997), The German Socio-Economic Panel: A Representative Sample of Reunited Germany and its Parts, DIW Vierteljahreshefte zur Wirtschaftsforschung, Vol. 1997(1), pp. 715.

Chase, R. (1995), Women's Labour Force Participation During and After Communism: A Case Study for the Czech Republic and Slovakia, Center Discussion Paper 768, Yale University, New Haven.

Cragg, J. (1971), Some Statistical Models for Limited Dependent Variables with Application to the Demand for Durable Goods, Econometrica, Vol. 39, pp. 829-844.

Dietrich, H. (1999), Jugendliche auf dem Weg in Ausbildung und Erwerbstätigkeit - Situation und Perspektiven, in: E. Wiedemann, C. Brinkmann, E. Spitznagel and U. Walwei (eds.), Die arbeitsmarkt- und beschäftigungspolitische Herausforderung in Ostdeutschland, Beiträge zur Arbeitsmarkt- und Berufsforschung, Vol.223, Nuremberg, pp. 247-265.

Franz, W. and V. Steiner (2000), Wages in the East German Transition Process - Facts and Explanations, German Economic Review, Vol. 1, 241-269.

Gourieroux, C. and A. Monfort (1993), Simulation Based Inference: A Survey with Special Reference to Panel Data, Journal of Econometrics, Vol. 59, pp. 5-34.

Gladisch, D. and L. Trabert (1995), Geschlechterspezifische Differenzierung der Erwerbsbeteiligung, Wirtschaft im Wandel, Vol. 1, 8-11.

Gronau, R. (1974), Wage Comparisons-A Selectivity Bias, Journal of Political Economy, Vol. 82, pp. 1119-43.

Grunert, R. (2000), Bei Annäherung weiterhin Besonderheiten der Konsumstruktur in Ostdeutschland, Wirtschaft im Wandel, Vol. 7, 204-209.

Gustafsson, S., C. Wetzels, J. Vlasblom and S. Dex (1996), Women's Labor Force Transitions after Childbirth: A Panel Data Comparison between Germany, Sweden and Great Britain, Journal of Population Economics, Vol. 9, pp. 223-246.

Heckman, J. (1979), Sample Selection Bias as a Specification Error, Econometrica, Vol. 47, pp. 153-161.

Hujer, R. and J. Grammig (1995), Nachfragerestriktionen des individuellen Arbeitsangebots in den USA und der Bundesrepublik Deutschland: Eine mikroökonometrische Analyse, in: V. Steiner and L. Bellmanm (ed.), Mikroökonomik des Arbeitsmarktes, Beiträge zur Arbeitsmarkt- und Berufsforschung, Vol. 192, Nuremberg, pp. 5187.

Hülser, O. (1996), Frauenerwerbstätigkeit im Transformationsprozeß der deutschen Vereinigung, Beiträge zur Arbeitsmarkt und Berufsforschung 194, Nuremberg. 


\section{William Davidson Institute Working Paper 477}

Hunt, J. (1999), Determinants of Non-employment and Employment Duration in East Germany, NBER Working Paper 7128.

Hunt, J. (2001a), The Transition in East Germany: When is a Ten Point Fall in the Gender Wage Gap Bad News?, forthcoming in Journal of Labor Economics

Hunt, J. (2001b), Post-unification Wage Growth in East Germany, Review of Economics and Statistics, Vol. 83, pp. 190-195.

Koller, B. (1999), Ältere - Eine Manövriermasse des Arbeitsmarktes? Ältere Arbeitnehmer in den neuen Bundesländern zwischen Vorruhestand und Erhöhung des Rentenzugangsalters, in: E. Wiedemann, C. Brinkmann, E. Spitznagel and U. Walwei (eds.), Die arbeitsmarkt- und beschäftigungspolitische Herausforderung in Ostdeutschland, Beiträge zur Arbeitsmarkt- und Berufsforschung, Vol. 223, Nuremberg, pp. 227-246.

Lange, T. and G. Pugh (1998), The Economics of German Unification: An Introduction, Cheltenham: Edward Elgar.

Lechner, M. (1998), Eine empirische Analyse des Geburtenrückgangs in den neuen Bundesländern aus Sicht der neoklassichen Bevölkerungsökonomie, Zeitschrift für Wirtschafts- und Sozialwissenschaften, 118, pp. 463-488.

Maddala, G. (1983), Limited-Dependent and Qualitative Variables in Econometrics, Econometric Society Monographs No. 3, Cambridge University Press.

Meyer, W. (1997), Individuelle Erwerbschancen in Ostdeutschland: Auswirkungen des wirtschaftsstrukturellen Wandels, Wiesbaden: Deutscher Universitätsverlag.

Poirier, D. (1980), Partial Observability in Bivariate Probit Models, Journal of Econometrics, Vol. 12, pp. $209-217$.

Spahn, P., H. Kaiser and T. Kassella (1994), The Taxation of Married Couples in Germany: Distributive and Allocative Aspects, in: M. Eichhorn (ed.), Models and Measurement of Welfare and Inequality, Berlin: Springer, pp. 361-395.

Statistics Germany (various issues), Bevölkerung und Erwerbstätigkeit, FS1, R. 4.1.1: Stand und Entwicklung der Erwerbstätigkeit, Wiesbaden.

Strøm, S. and G. Wagenhals (1991), Female Labour Supply in the Federal Republic, Jahrbücher für Nationalökonomie und Statistik, Vol 208, pp. 575-595.

Svejnar, J. (1999), Labor Markets in the Transitional Central and East European Economies, in O. Ashenfelter and D. Card (ed.) Handbook of Labor Economics, Vol. 3B, Elsevier Science B.V., pp. 2809-2857. 
William Davidson Institute Working Paper 477

Figure 1: Female Labor Force Participation Rates in East and West Germany
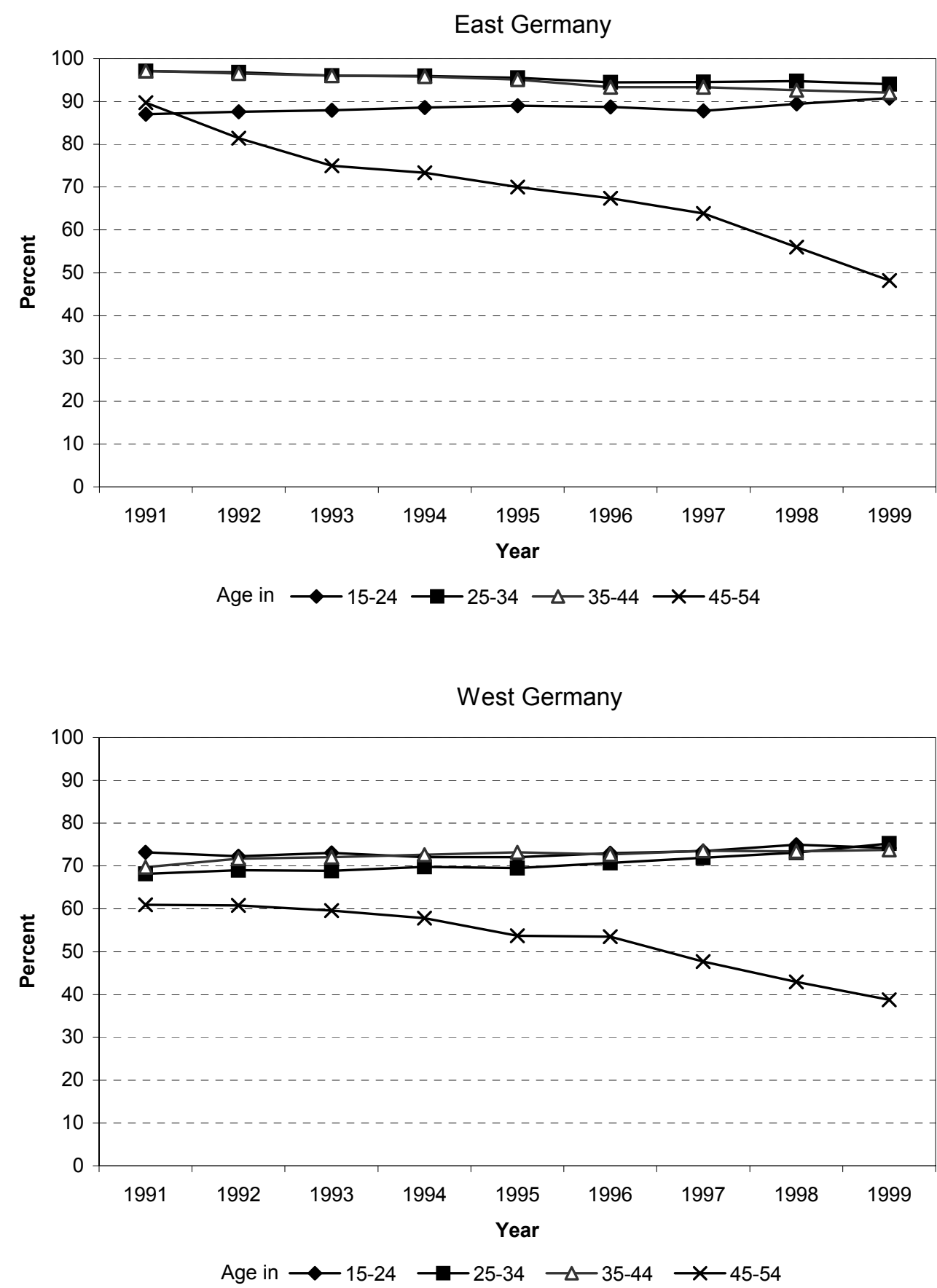

Source: Statistics Germany (various issues), own calculations 
William Davidson Institute Working Paper 477

Figure 2: Simulations of Female Labor Force Participation Rates
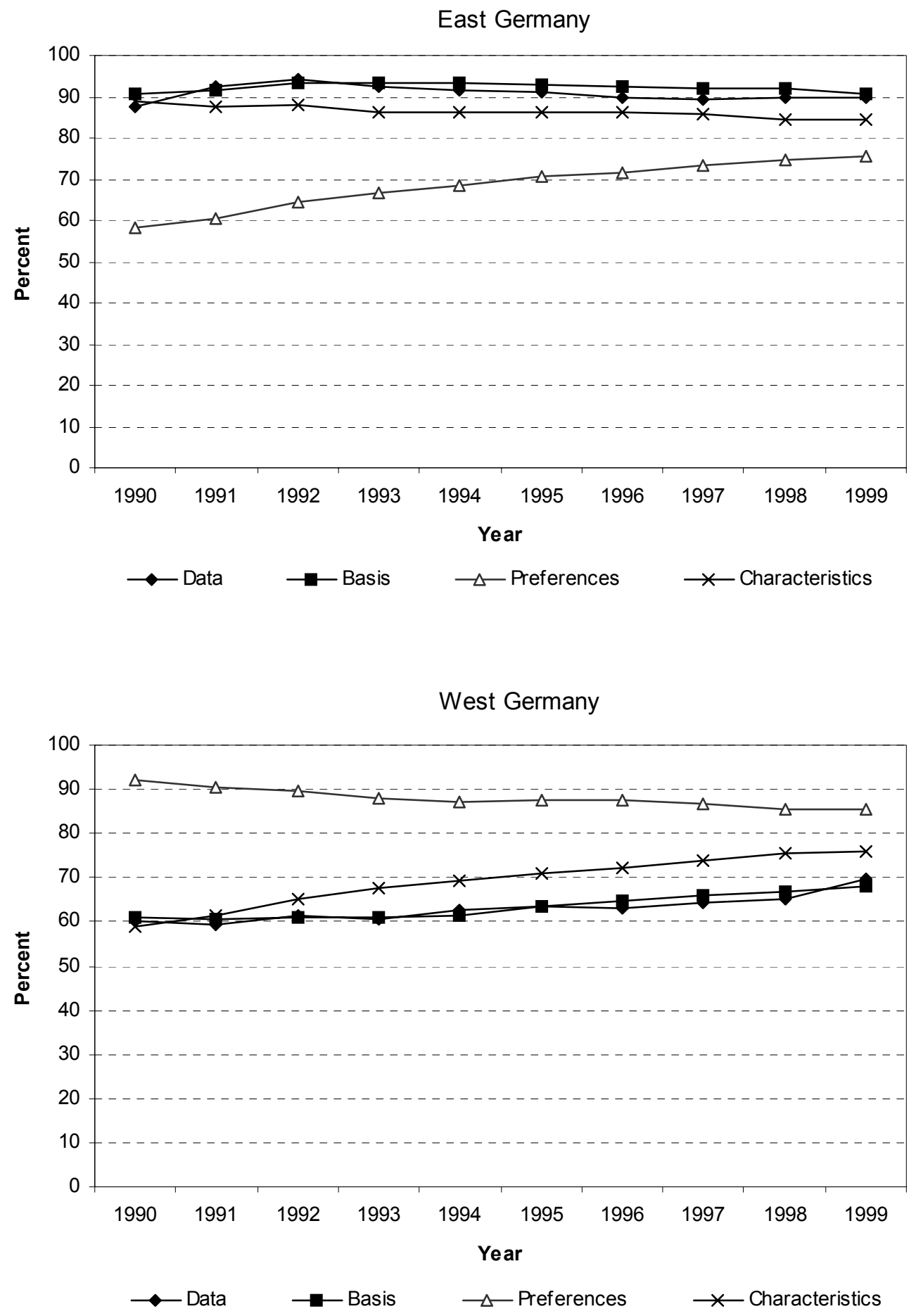

Explanation: The basic simulation is on the basis of own parameters and own individual characteristics, the preferences simulation uses the counterfactual parameters of the participation equation, and the characteristics simulation uses the counterfactual individual characteristics. 
William Davidson Institute Working Paper 477

Table 1: Sample Statistics, Married and Cohabiting Women (ages 25-44 at unification)

\begin{tabular}{|c|c|c|c|c|c|c|c|c|c|c|}
\hline West-German Women & 1990 & 1991 & 1992 & 1993 & 1994 & 1995 & 1996 & 1997 & 1998 & 1999 \\
\hline (observations) & 880 & 901 & 889 & 857 & 882 & 880 & 833 & 829 & 773 & 761 \\
\hline$\overline{\text { Age }}$ & 34.16 & 35.11 & 35.93 & 36.91 & 37.78 & 38.80 & 39.65 & 40.71 & 41.58 & 42.63 \\
\hline Participation & 0.60 & 0.59 & 0.61 & 0.60 & 0.63 & 0.63 & 0.63 & 0.64 & 0.65 & 0.70 \\
\hline Employment & 0.57 & 0.57 & 0.58 & 0.58 & 0.59 & 0.59 & 0.61 & 0.61 & 0.63 & 0.66 \\
\hline Gross hourly wage & 19.40 & 19.86 & 20.55 & 20.86 & 21.76 & 23.27 & 23.32 & 21.68 & 22.62 & 21.95 \\
\hline \multicolumn{11}{|l|}{ Number of children } \\
\hline Between $0-2$ years & 0.20 & 0.19 & 0.18 & 0.18 & 0.17 & 0.13 & 0.11 & 0.09 & 0.10 & 0.07 \\
\hline Between 3-5 years & 0.27 & 0.27 & 0.24 & 0.25 & 0.23 & 0.23 & 0.22 & 0.19 & 0.16 & 0.13 \\
\hline Between 6-16 years & 0.71 & 0.74 & 0.80 & 0.82 & 0.84 & 0.84 & 0.84 & 0.81 & 0.80 & 0.78 \\
\hline \multicolumn{11}{|l|}{$\underline{\text { Husbands }}$} \\
\hline Age & 37.19 & 38.14 & 38.94 & 39.97 & 40.72 & 41.67 & 42.46 & 43.47 & 44.32 & 45.39 \\
\hline Employed & 0.95 & 0.95 & 0.95 & 0.95 & 0.93 & 0.93 & 0.93 & 0.91 & 0.90 & 0.91 \\
\hline Gross hourly wage & 27.80 & 28.51 & 29.51 & 30.43 & 31.72 & 32.11 & 32.30 & 32.24 & 32.46 & 33.79 \\
\hline Benefit (1.000 DEM) & 1.08 & 1.21 & 1.31 & 1.64 & 1.69 & 1.59 & 1.80 & 1.62 & 1.78 & 1.97 \\
\hline East-German Women & 1990 & 1991 & 1992 & 1993 & 1994 & 1995 & 1996 & 1997 & 1998 & 1999 \\
\hline (observations) & 764 & 717 & 717 & 659 & 651 & 642 & 608 & 577 & 552 & 538 \\
\hline Age & 34.08 & 35.05 & 35.89 & 37.17 & 37.91 & 38.99 & 39.87 & 40.98 & 41.81 & 41.81 \\
\hline Participation & 0.88 & 0.92 & 0.94 & 0.93 & 0.92 & 0.91 & 0.90 & 0.89 & 0.90 & 0.90 \\
\hline Employment & 0.88 & 0.79 & 0.72 & 0.73 & 0.72 & 0.75 & 0.74 & 0.75 & 0.75 & 0.75 \\
\hline Gross hourly wage & 10.54 & 12.20 & 15.67 & 16.96 & 18.45 & 20.33 & 20.17 & 20.28 & 21.04 & 21.03 \\
\hline \multicolumn{11}{|l|}{ Number of children } \\
\hline Between $0-2$ years & 0.17 & 0.13 & 0.07 & 0.05 & 0.04 & 0.03 & 0.03 & 0.02 & 0.02 & 0.02 \\
\hline Between $3-5$ years & 0.27 & 0.23 & 0.23 & 0.18 & 0.14 & 0.10 & 0.06 & 0.06 & 0.04 & 0.04 \\
\hline Between 6-16 years & 1.00 & 1.06 & 1.07 & 1.05 & 1.06 & 1.03 & 1.00 & 0.89 & 0.83 & 0.83 \\
\hline \multicolumn{11}{|l|}{ Husbands } \\
\hline Age & 36.84 & 37.76 & 38.74 & 39.89 & 40.60 & 41.71 & 42.58 & 43.65 & 44.59 & 44.59 \\
\hline Employed & 0.98 & 0.94 & 0.91 & 0.89 & 0.89 & 0.89 & 0.86 & 0.86 & 0.83 & 0.83 \\
\hline Gross hourly wage & 12.05 & 15.64 & 17.46 & 18.53 & 20.37 & 21.52 & 21.83 & 21.81 & 22.78 & 23.07 \\
\hline Benefit (1.000 DEM) & 0.96 & 1.18 & 1.26 & 1.27 & 1.29 & 1.30 & 1.32 & 1.33 & 1.33 & 1.37 \\
\hline
\end{tabular}

Note: Wages and benefits are measured in real 1991 German Marks. The wages are calculated only for the employed, while the benefits are calculated only for the husbands receiving a benefit. 
William Davidson Institute Working Paper 477

Table 2: Estimation Results, East-German women

\begin{tabular}{|c|c|c|c|c|c|c|c|}
\hline & \multicolumn{2}{|c|}{ Participation } & \multicolumn{2}{|c|}{ Job-offer } & \multicolumn{2}{|c|}{ Ln(wage) } & \multirow[b]{3}{*}{ Individual char. } \\
\hline & par. & s.e. & par. & s.e. & par. & s.e. & \\
\hline Individual char. & & & & & & & \\
\hline Constant & 2.9631 & 1.8588 & -0.9308 & 2.0324 & 1.4840 & $0.3839 * * *$ & Constant \\
\hline Age & -0.1245 & 0.1075 & 0.0488 & 0.1075 & 0.0391 & $0.0217^{*}$ & Age \\
\hline Age2 & 0.0016 & 0.0015 & -0.0005 & 0.0015 & -0.0005 & 0.0003 & Age2 \\
\hline Education & & & & & & & Education \\
\hline General & & & & & 0.0960 & 0.3281 & General \\
\hline General x Age & & & & & -0.0090 & 0.0087 & General x Age \\
\hline Vocational & & & & & -0.0951 & 0.1254 & Vocational \\
\hline Vocational x Age & & & & & 0.0104 & $0.0035^{* * *}$ & Vocational x Age \\
\hline University & & & & & 0.1782 & 0.1953 & University \\
\hline University x Age & & & & & 0.0091 & 0.0054 * & University $\times$ Age \\
\hline$\underline{\text { Interaction Time }}$ & & & & & & & $\underline{\text { Interaction Time }}$ \\
\hline Age $\times$ Time & -0.0096 & $0.0049 * *$ & -0.0013 & 0.0039 & -0.0002 & 0.0008 & Age $\times$ Time \\
\hline General x Time & & & & & 0.0012 & 0.0197 & General x Time \\
\hline Vocational x Time & & & & & 0.0047 & 0.0075 & Vocational x Time \\
\hline University x Time & & & & & 0.0190 & 0.0104 * & University $x$ Time \\
\hline Wage & & & & & & & Wage \\
\hline Ln(wage) & 0.8186 & $0.1882^{* * *}$ & 0.6248 & $0.2694^{* *}$ & & & Ln(wage) \\
\hline Ln(wage) $x$ Time & & & 0.1373 & 0.0606 ** & & & \\
\hline Number of Children & & & & & & & Year \\
\hline $0-2$ years & -1.8369 & $0.2066 * * *$ & & & -0.1210 & $0.0399 * * *$ & 1990 \\
\hline $3-5$ years & -0.4112 & $0.1444^{\star * *}$ & & & 0.0000 & 0.0000 & 1991 \\
\hline $6-16$ years & 0.0104 & 0.0823 & & & 0.1955 & $0.0425^{* * *}$ & 1992 \\
\hline$\underline{\text { Interaction Time }}$ & & & & & 0.2425 & 0.0664 *** & 1993 \\
\hline $0-2$ years $x$ Time & -0.0531 & 0.0510 & & & 0.3195 & $0.0948^{* * *}$ & 1994 \\
\hline $3-5$ years $x$ Time & -0.0770 & $0.0407^{*}$ & & & 0.3638 & $0.1255^{* * *}$ & 1995 \\
\hline $6-16$ years $x$ Time & -0.0286 & 0.0191 & & & 0.3608 & $0.1577^{\star *}$ & 1996 \\
\hline$\underline{\text { Husband }}$ & & & & & 0.3620 & 0.1914 ** & 1997 \\
\hline Ln(wage) & -0.1830 & 0.1196 & & & 0.3768 & $0.2257^{*}$ & 1998 \\
\hline Non-employed & -0.1100 & 0.5033 & & & 0.3685 & 0.2621 & 1999 \\
\hline Ln(benefit) & -0.0703 & 0.0572 & & & & & \\
\hline \multicolumn{8}{|l|}{$\underline{\text { Region }}$} \\
\hline Unemployment rate & & & -3.5179 & $2.3703^{*}$ & & & \\
\hline Vacancy rate & & & -1.8011 & 2.4475 & & & \\
\hline \multicolumn{8}{|l|}{ Year } \\
\hline Time & 0.2556 & 0.1828 & -0.4680 & $0.1979 * *$ & & & \\
\hline Time2 & 0.0106 & 0.0072 & 0.0237 & $0.0073^{* \star *}$ & & & \\
\hline
\end{tabular}

Note: Parameters marked with *,** or $* * *$ are significant at a 10,5 and 1 percent significance level, respectively. 
William Davidson Institute Working Paper 477

Table 3: Estimation Results on Variances and Covariances

\begin{tabular}{|c|c|c|c|c|c|c|}
\hline & \multicolumn{2}{|c|}{ Participation } & \multicolumn{2}{|c|}{ Job-offer } & \multicolumn{2}{|c|}{ Ln(wage) } \\
\hline & par. & s.e. & par. & s.e. & par. & s.e. \\
\hline \multicolumn{7}{|l|}{ East-German women } \\
\hline \multicolumn{7}{|l|}{ Standard deviations } \\
\hline Idiosyncratic errors & 1.0000 & 0.0000 & 1.0000 & 0.0000 & 0.3311 & $0.0081^{* * *}$ \\
\hline Individual errors & 0.2851 & $0.1651^{*}$ & 0.4518 & $0.1885^{* *}$ & 0.0000 & 0.0000 \\
\hline \multicolumn{7}{|l|}{$\underline{\text { Covariances }}$} \\
\hline Idiosyncratic errors & & & 0.0000 & 0.0000 & & \\
\hline Individual errors & & & -0.1256 & 0.1018 & & \\
\hline \multicolumn{7}{|l|}{ West-German women } \\
\hline \multicolumn{7}{|l|}{ Standard deviations } \\
\hline Idiosyncratic errors & 1.0000 & 0.0000 & 1.0000 & 0.0000 & 0.4677 & $0.0108^{* * *}$ \\
\hline Individual errors & 0.2360 & 0.1398 * & 0.3337 & 0.2177 & 0.0491 & 0.0670 \\
\hline \multicolumn{7}{|l|}{$\underline{\text { Covariances }}$} \\
\hline Idiosyncratic errors & & & 0.0000 & 0.0000 & & \\
\hline Individual errors & & & 0.0557 & 0.0726 & & \\
\hline
\end{tabular}

Note: The only identified covariances are between the participation and the job-offer equation; see Appendix A. The standard deviations of the idiosyncratic error terms of the participation and the job-offer equation are set equal to one by means of normalization. Some of the standard deviations and covariances are set equal to zero as they converged to zero within the maximum likelihood optimization procedure. 
William Davidson Institute Working Paper 477

Table 4: Estimation Results, West-German women

\begin{tabular}{|c|c|c|c|c|c|c|c|}
\hline & \multicolumn{2}{|c|}{ Participation } & \multicolumn{2}{|c|}{ Job-offer } & \multicolumn{2}{|c|}{ Ln(wage) } & \\
\hline & par. & s.e. & par. & s.e. & par. & s.e. & \\
\hline Individual char. & & & & & & & Individual char. \\
\hline Constant & -1.0717 & 1.4652 & -2.9550 & 3.2365 & 2.3529 & $0.5944 * * *$ & Constant \\
\hline Age & 0.1103 & 0.0749 & 0.1871 & $0.1037^{*}$ & 0.0226 & 0.0299 & Age \\
\hline Age2 & -0.0019 & $0.0010^{*}$ & -0.0021 & 0.0019 & -0.0003 & 0.0004 & Age2 \\
\hline Education & & & & & & & Education \\
\hline General & & & & & -0.0069 & 0.2693 & General \\
\hline General x Age & & & & & -0.0046 & 0.0066 & General x Age \\
\hline Vocational & & & & & 0.2163 & 0.3351 & Vocational \\
\hline Vocational x Age & & & & & -0.0020 & 0.0084 & Vocational x Age \\
\hline University & & & & & -0.4379 & 0.2974 & University \\
\hline University $\times$ Age & & & & & 0.0225 & $0.0074^{* * *}$ & University x Age \\
\hline Interaction Time & & & & & & & Interaction Time \\
\hline Age $\times$ Time & & & & & & & Age $\times$ Time \\
\hline General x Time & & & & & & & General x Time \\
\hline Vocational x Time & & & & & & & Vocational x Time \\
\hline University $\mathrm{x}$ Time & & & & & & & University x Time \\
\hline Wage & & & & & & & Wage \\
\hline Ln(wage) & 0.3491 & $0.1609^{* * *}$ & 0.2000 & 0.5679 & & & Ln(hourly wage) \\
\hline Ln(wage) $x$ Time & & & 0.0408 & 0.1184 & & & \\
\hline Number of Children & & & & & & & Year \\
\hline $0-2$ years & -1.2881 & $0.1294 * * *$ & & & -0.0027 & 0.0699 & 1990 \\
\hline $3-5$ years & -0.6886 & $0.1051^{* \star *}$ & & & 0.0000 & 0.0000 & 1991 \\
\hline $6-16$ years & -0.2569 & $0.0620 * * *$ & & & 0.0296 & 0.0688 & 1992 \\
\hline$\underline{\text { Interaction Time }}$ & & & & & 0.0405 & 0.0684 & 1993 \\
\hline $0-2$ years $x$ Time & -0.0429 & 0.0267 * & & & 0.0613 & 0.0677 & 1994 \\
\hline 3-5 years $x$ Time & -0.0194 & 0.0265 & & & 0.1065 & $0.0666^{*}$ & 1995 \\
\hline $6-16$ years $x$ Time & -0.0099 & 0.0138 & & & 0.1157 & 0.0694 * & 1996 \\
\hline$\underline{\text { Husband }}$ & & & & & 0.0623 & 0.0712 & 1997 \\
\hline Ln(wage) & -0.1686 & 0.0894 * & & & 0.0945 & 0.0712 & 1998 \\
\hline Non-employed & 0.2201 & 0.4139 & & & 0.0571 & 0.0717 & 1999 \\
\hline Ln(benefit) & -0.0903 & $0.0427^{* \star *}$ & & & & & \\
\hline$\underline{\text { Region }}$ & & & & & & & \\
\hline Unemployment rate & & & 0.6853 & 4.1118 & & & \\
\hline Vacancy rate & & & 1.3402 & 1.3741 & & & \\
\hline Year & & & & & & & \\
\hline Time & 0.0295 & 0.0414 & -0.1377 & 0.3381 & & & \\
\hline Time2 & 0.0014 & 0.0050 & -0.0008 & 0.0107 & & & \\
\hline
\end{tabular}

Note: Parameters marked with ${ }^{*},{ }^{*}$ or $* * *$ are significant at a 10,5 and 1 percent significance level, respectively. 


\section{DAVIDSON INSTITUTE WORKING PAPER SERIES - Most Recent Papers}

The entire Working Paper Series may be downloaded free of charge at: www.wdi.bus.umich.edu

CURRENT AS OF 7/10/02

\begin{tabular}{|c|c|c|}
\hline Publication & Authors & Date \\
\hline $\begin{array}{l}\text { No. 477: Participation Behavior of East German Women after German } \\
\text { Unification }\end{array}$ & Holger Bonin and Rob Euwals & July 2002 \\
\hline No. 476: Duration and Risk of Unemployment in Argentina & $\begin{array}{l}\text { Sebastian Galiani and Hugo A. } \\
\text { Hopenhayn }\end{array}$ & Oct. 2001 \\
\hline $\begin{array}{l}\text { No. 475: After, Before and During: Returns to Education in the } \\
\text { Hungarian Transition }\end{array}$ & $\begin{array}{l}\text { Nauro F. Campos and Dean } \\
\text { Jolliffe }\end{array}$ & Apr. 2002 \\
\hline No. 474: The Locking-in Effect of Subsidized Jobs & Jan C. van Ours & June 2002 \\
\hline No. 473: How Reform Worked in China & Yingyi Qian & June 2002 \\
\hline No. 472: An Economic Perspective on Russia's Accession to the WTO & Robert M. Stern & June2002 \\
\hline $\begin{array}{l}\text { No. 471: The Effects of Ownership Forms and Concentration on Firm } \\
\text { Performance after Large-Scale Privatization }\end{array}$ & Evzen Kocenda and Jan Svejnar & May 2002 \\
\hline $\begin{array}{l}\text { No. 470: Growth in Transition: What We Know, What We Don't, and } \\
\text { What We Should }\end{array}$ & $\begin{array}{l}\text { Nauro F. Campos and Fabrizio } \\
\text { Coricelli }\end{array}$ & Feb. 2002 \\
\hline $\begin{array}{l}\text { No. 469: Barriers to Investment by Russian Firms: Property Protection } \\
\text { or Credit Constraints? }\end{array}$ & Susan J. Linz & May 2002 \\
\hline No. 468: Job Satisfaction Among Russian Workers & Susan J. Linz & May 2002 \\
\hline $\begin{array}{l}\text { No. 467: Assessing the Problem of Human Capital Mismatch in } \\
\text { Transition Economies }\end{array}$ & $\begin{array}{l}\text { Viliam Druska, Byeong ju Jeong, } \\
\text { Michal Kejak, and Viatcheslav } \\
\text { Vinogradov }\end{array}$ & Mar. 2002 \\
\hline $\begin{array}{l}\text { No. 466: Motivating Russian Workers: Analysis of Age and Gender } \\
\text { Differences }\end{array}$ & Susan J. Linz & Feb. 2002 \\
\hline No. 465: Virtual Reality: Barter and Restructuring in Russian Industry & Gary Krueger and Susan J. Linz & Apr. 2001 \\
\hline $\begin{array}{l}\text { No. 464: Lending of Last Resort, Moral Hazard and Twin Crises: } \\
\text { Lessons from the Bulgarian Financial Crisis 1996/1997 }\end{array}$ & $\begin{array}{l}\text { Michael Berlemann, Kalin } \\
\text { Hristov and Nikolay Nenovsky }\end{array}$ & May 2002 \\
\hline $\begin{array}{l}\text { No. 463: Deindustrialisation. Lessons from the Structural Outcomes of } \\
\text { Post-Communist Transition }\end{array}$ & $\begin{array}{l}\text { Tomasz Mickiewicz and Anna } \\
\text { Zalewska }\end{array}$ & Jan. 2002 \\
\hline $\begin{array}{l}\text { No. 462: Joint Liability Lending and the Rise and Fall of China's } \\
\text { Township and Village Enterprises }\end{array}$ & Albert Park and Minggao Shen & July 2001 \\
\hline $\begin{array}{l}\text { No. 461: A Refinancing Model of Decentralization with Empirical } \\
\text { Evidence from China }\end{array}$ & Albert Park and Minggao Shen & Apr. 2002 \\
\hline $\begin{array}{l}\text { No. 460: The Effects of Market Liberalization on the Relative Earnings } \\
\text { of Chinese Women }\end{array}$ & $\begin{array}{l}\text { Margaret Maurer-Fazio and } \\
\text { James Hughes }\end{array}$ & Mar. 2002 \\
\hline $\begin{array}{l}\text { No. 459: The Role of Education in Determining Labor Market } \\
\text { Outcomes in Urban China's Transitional Labor Markets }\end{array}$ & Margaret Maurer-Fazio & Apr. 2002 \\
\hline $\begin{array}{l}\text { No. 458: Real and Monetary Convergence within the European Union } \\
\text { and Between the European Union and Candidate Countries: } \\
\text { A Rolling Cointegration Approach }\end{array}$ & $\begin{array}{l}\text { Josef C. Brada, Ali M. Kutan and } \\
\text { Su Zhou }\end{array}$ & Apr. 2002 \\
\hline No. 457: Credit Ratings as Coordination Mechanisms & $\begin{array}{l}\text { Arnoud W. A. Boot and Todd T. } \\
\text { Milbourn }\end{array}$ & Mar. 2002 \\
\hline $\begin{array}{l}\text { No. 456: Balkan and Mediterranean Candidates for European Union } \\
\text { Membership: The Convergence of their Monetary Policy with that of the } \\
\text { European Central Bank }\end{array}$ & Josef C. Brada and Ali M. Kutan & Apr. 2002 \\
\hline $\begin{array}{l}\text { No. 455: Russian Financial Transition: The Development of Institutions } \\
\text { and Markets for Growth }\end{array}$ & David M. Kemme & Oct. 2001 \\
\hline $\begin{array}{l}\text { No. 454: Does the Market Pay Off? Earnings Inequality and Returns to } \\
\text { Education in Urban China }\end{array}$ & Xiaogang $\mathrm{Wu}$ and $\mathrm{Yu} \mathrm{Xie}$ & Apr. 2002 \\
\hline $\begin{array}{l}\text { No. 453: Entrepreneurs' Access to Private Equity in China: } \\
\text { The Role of Social Capital }\end{array}$ & Bat Batjargal and Mannie M. Liu & Apr. 2002 \\
\hline
\end{tabular}

